\title{
Plant growth promoting Rhizobacteria: Biocontrol potential for pathogens
}

\author{
Roomina Mazhar*, Noshin Ilyas, Naveed Iqbal Raja, Maimona Saeed, \\ Mubashir Hussain, Wajiha Seerat, Huma Qureshi and Sumera Shabir \\ Department of Botany PMAS, Arid Agriculture University, Rawalpindi-Pakistan \\ *Corresponding author's email: roominamazhar83@gmail.com \\ Citation \\ Roomina Mazhar, Noshin Ilyas, Naveed Iqbal Raja, Maimona Saeed, Mubashir Hussain, Wajiha Seerat, Huma \\ Qureshi and Sumera Shabir. Plant growth promoting Rhizobacteria: Biocontrol potential for pathogens. Pure and \\ Applied Biology. Vol. 5, Issue 4, pp1288-1295. http://dx.doi.org/10.19045/bspab.2016.50154
}

\begin{tabular}{llll}
\hline Received: 20/06/2016 & Revised: 06/10/2016 & Accepted: 12/10/2016 & Online First: 02/12/2016 \\
\hline
\end{tabular}

\section{Abstract}

Plant growth promoting rhizobacteria (PGPR) are groups of free living Rhizospheric bacteria which can enhance plant growth under normal as well as stress conditions. One of the major issues of agricultural crops is a reduction in yield by different pathogens, which affect many staple crops. So there is a need to develop some strategies for preventing the crops from different pathogens. Several PGPR such as Pseudomonas, Azospirillum, Rhizobium and Bacillus species can promote plant growth under stress condition by suppressing the growth of pathogenic organisms. PGPR stimulate plant growth by various mechanisms, for example induce systemic resistance. PGPR produce siderophores, antibiotics and degrade virulence factor against pathogenic attack, which inhibits the growth of pathogenic and protect the plant. In spite of the importance of PGPR in crop production system present review focuses on different ways adopted by PGPR to prevent crops from pathogen and increase their yield.

Keywords: PGPR; Biocontrol; Pathogen; Rhizosphere

\section{Introduction}

Plant growth promoting rhizobacteria are mostly symbiotic bacteria or free living in nature and most often present in rhizosphere of plants which exert a positive effect on plant by their biocontrol activity against pathogenic organisms. PGPR can suppress the broad range of pathogenic microbes including virus, bacteria and fungi. PGPR are considered to be an important biocontrol tool in various parts of the world, but this is applicable at experimental level and need to be explored at field level [1].

In this context PGPR are focal point of many agronomists and microbiologist due to their mitigation potential against a range of biotic stresses [2]. Various species of genus Pseudomonas [3] Bacillus [4] and Azospirillum were tested for important economic crops [5]. Recently, several attempts have been made for the development and application of inoculants for disease management [6] and stress tolerance in plants [7].

Rhizosphere microorganisms impart direct effect on plants through biofertilization and phytostimulation. The mechanisms involved are phosphate solublization, nitrogen fixation, synthesis of phytohormones and availability of other nutrients in soil [8]. By several indirect mechanisms microbes also impart positive effect on plants by 
decreasing population density of pathogens through lysis, production of several metabolites hyperparasitism and antibiosis. PGPR most often act by induction of induce systemic resistance, detoxification and degradation of virulence factors, siderophores production, synthesis of antibiotics through qurom sensing and detoxification of virulence factors $[9,10]$. These biocontrol mechanisms are adopted by microbes for competing other microbes for space and nutrients which indirectly support the plant for better growth and tolerance towards biotic stress.

\section{Plant-microorganism interactions;}

\section{Ecological implications}

The interactions among plant and microbes often occurs in rhizospheric soil which can improve growth and plant environmental adaptation . Soil-borne microbes colonize the roots of plants at the root-soil interface, heterotrophic biota obtained food from root exudates and decaying plant material as carbon source [11]. The bacterial community most often resides in the rhizoplane and rhizosphere. A large amount of different amino acids, organic acids and vitamins are released in surrounding soil as seed starts to germinate. The accumulation of these attractive compounds leads towards a shift in grater microbial diversity as than before inducing competition [12]. The bacterial communities living in close vicinity of one particular plant species may vary greatly with the bacterial communities residing with any other plant [11].

There are several groups of microbes including aerobic, anaerobic and micro aerobes associated with the plant roots, rhizosphere. Some of them live or associated with various plant tissues such as roots stem, seeds and tubers [13]. Another important bacterial group, the entophytic bacteria most often colonize the internal tissues of host plants and are very important for biocontrol of various diseases of plants as they are growing in the same tissue or organ which is effected by the pathogen [14]. Diazotrophic bacterial species are large group of plant associated bacteria that do not form any nodule like structures including Azospirillum species [15]. Diazotrophic bacteria can positively effects the plant growth and development and defend plant from pathogenic attack rather than present in less numbers [16]. However, some members of these bacterial group including Bacillus, Azospirillum (A. brasilense) and Pseudomonas (P. fluorescens) may colonize the internal surfaces of roots [17].

The importance of PGPR as biocontrol agents for production of crops systems is just beginning and PGPR support growth in several agronomic important crops and not only acts as biofertilizer but can enhance plant growth under stress conditions [13]. Few of the biocontrol mechanism are elaborated here in this review as including the followings.

\section{Defense mechanisms (ISR) mediated by PGPR}

Non-pathogenic rhizosphere bacteria after inoculation can activates certain signaling pathways when receives any pathogenic or stress stimulus, this stimulus also produce pathogen resistance in host, the whole mechanism is termed as induce systemic resistance. Systemic response in plants can be induced by activating plant defense mechanisms due to many rhizosphere microorganisms. Various chemical and physical changes are induced due to several PGPR in host plant in reaction to abiotic and biotic stress conditions. The term induced systemic tolerance may also be used for the changes occurring in plants due to PGPR. Bacillus is well studied to induce ISR under abiotic stress condition [18].

Once any PGPR receives any abiotic or biotic stress or attacked by any pathogen, PGPR activates the synthesis of various plant defense chemicals which leads towards 
or fortify the plant metabolic responses, fortify plant cell wall and induce changes in physiology of host plant [19, 20]. After challenge with a pathogen he bacterized plant response induced changes at pathogenic attack site such as the formation of structural barriers due to callose deposition and phenolic compounds accumulation [21].

Accumulation of certain phenolic compounds and strengthening of cell wall in several cortical cell layers was observed during the endophytic colonization of the bacterium in a host defense reaction in PsJN-grapevine Burkholderia phytofirmans interaction [22]. In tomato plant after inoculation with endophytic $P$. fluorescens WCS417r the outermost part of the radial side of the first layer cell walls and the outer tangential walls got thickened when hypodermal or epidermal cells were colonized [23]. Accumulation of pathogenesis-related proteins (PR proteins) such as PR-1, PR-2, peroxidases and chitinases, are also part of physiological or biochemical changes in plants. Induction of PR proteins is not only part of the defenses mechanism rather than production of such pathogenesis related proteins several bacteria accumulates a considerable or significant amount of phytoalexins, polyphenol oxidase, chalcone synthase and peroxidases $[24,20]$. The synthesis of above plant defense compounds activated by the same molecules including $N$-acyl homoserine lactones which are used for qurom sensing/ cell signaling mechanisms [25]. The genes involved in biosynthesis of these defense related compound e.g. chalcone synthase are homologous with the plant defense related genes under stress conditions. This revelation is thus intriguing but still there is possibility that the products of these DeVriesien-like pangens may have interspecies activity benefiting plant protection [26, 27]. Infect there is an intercommunication between the metabolic pathways of plant defense and other stress responses [28].

\section{Degradation and Detoxification of virulence factors}

Detoxification effect due to pathogen virulence factor is one of the biocontrol mechanisms. For example different microbes elicits the ability to degrade or detoxify the pathogenic compounds secreted in or around the vicinity of that microorganisms. Furthermore the co inoculation of these microbes with plants strengthen the defensive mechanism against several pathogenic microbes. Strains of Ralstonia solanacearum and B. cepacia has the ability to degrade the fusaric acid phytotoxin which is released by various Fusarium species [29].

Biocontrol activity is most often exhibited by various pathogenic and non-pathogenic strains for species survival and competition for space and nutrients. Every microbe most often has several signaling molecules for sensing the presence of other microbes in vicinity as well as several virulence factors for its own survival by killing the microbe nearby. Several pathogenic microbes exhibits broad spectrum pathogenic activity against biocontrol agents acts as self-defense methods by detoxifying the antibiotics secreted by biocontrol microorganisms and hence suppress the overall growth. The Xanthomonas albilineans produce albicidin toxin could be detoxified by several other bacterial strains. Production of proteins is reported in various microbes such as Alcaligenes denitrificans, Klebsiella oxytoca during detoxification mechanism moreover, in Pantoea dispersa irreversible detoxification of albicidin mediated by an esterase also occurred [30].

Inplanta, production of antibiotics is reported by endophytic $P$. fluorescens strain FPT 9601 in tomato roots where it can secrets DAPG. The ability to degrade any 
virulence factor or inhibition of pathogenic growth most often decreases with the colonization of interior parts of host tissues for example in potato tubers, it may leads towards the hypothesis that the adaptation of bacterial strains may be tissue or site specific within their host [31]. Genes for virulence factors can be turned on due to auto inducers mediated quorum sensing in bacterial plant pathogens [32]. PGPR have the ability to reduce pathogen quorum sensing capability for stopping the gene expression of various pathogenic or virulence genes by degrading auto inducers signals. This approaches tremendous potential for cure of different diseases and can be manifested even after onset of diseases [33].

Free-living rhizobacteria have the ability to synthesize various allele chemicals for biocontrol activity this similar mechanism is also exhibited by endophytic bacteria as these bacteria can also produce certain compounds with antagonistic activity [34]. Antibiotics mumbicins, created by the endophytic bacterium Streptomyces sp. strain NRRL 30562 can inhibit in vitro growth of phytopathogenic fungi, $F$. oxysporum and P. ultimum [35].

\section{Siderophore Productionn}

Iron is an essential element for almost all living organisms to run their all metabolic processes smoothly. A furious competition may arise in soil due to unavailability or scarcity of available iron to the soil microbiota as well as for plant. To maximize the availability and adsorption of iron from soil microbes have adapted several mechanism to cope up with these condition which in terms leads towards stability in that regimes. Low molecular weight compounds termed as "siderophores" are excreted in soil by PGPB to absorb ferric ion under iron limiting conditions [6]. Siderophores are released by microbes through active transport mechanisms to scavenge the iron in form of ${ }^{+3} \mathrm{Fe}$ [36]. Several siderophores are biosynthesized independently and some are non-ribosomal peptides in nature [37].

For iron acquisition pathogenic bacteria are also dependent upon siderophores. Among several siderophores secreted by microbes for example enterobactin one of the strongest binder of iron [38]. Bacillus, Enterobacter genera and Pseudomonas are some of the isolated gram negative bacteria which secrete siderophores under iron limiting conditions, in gram positive bacteria the Rhodococcus genera are quite efficient [39]. Siderophores production can also act as biocontrol mechanism which can deprive pathogenic fungi for iron as scarcely bioavailable element [40].

\section{Antibiosis}

Foundation of antibiosis as a biocontrol tool of PGPB has become increasingly better developed from last two decades [41]. Small, squat molecular weight hetrogenous substances that inhibits the metabolic and growth functions of other microbes are termed as antibiotics [42]. Antibiotic production plays an important role for pathogenic inhibition and plant defense mechanism e.g six antibiotic groups including phloroglucinols, pyrrolnitrin, pyoluteorin, phenazines, cyclic lipopeptides and hydrogen cyanide acts as inhibitors of root diseases [43].

Furthermore, wide range of antibiotics or antibiotic related substances produced by PGPR such as kanosamine, oligomycin A, xanthobaccin and zwittermicin A. produced by Stenotrophomonas spp, Streptomyces, and Bacillus [21]. Amphisin, oomycin A, tropolone, phenazine, 2,4diacetylphloroglucinol (DAPG), pyrrolnitrin, tensin, and cyclic lipopeptides produced by pseudomonas. Not only the biocontrol defense purposes these antibiotics are also very crucial for certain pathogenic diseases and can be used as new experimental pharmaceuticals [44]. 
Plant growth promoting bacteria colonize the root rhizosphere and protects important crop plants from several broad spectrum microbes by production of antibiotics such as 2,4-diacetylphloroglucinol produced by fluorescent pseudomonas. A very important and vigorously studied antibioti (DAPG) decrease the impact of phytium spp. by suppressing the zoospores [45]. Damping of disease as a result of Rhizoctonia solani which effects the cotton plant can be decreased by Pyrrolnitrin, the antibiotic produced by the $P$. fluorescens BL915 strain, $F$. oxysporum and Gaeumannomyces graminis both of plant pathogen could be killed by Phenazine, exercted by pseudomonas, [46]. Bacillus spp. secretes antiobtics such as colistin, polymyxin and circulin have strong potential to kill certain pathogenic fungi and gram negative and positive bacteria [47]. Phenazine-1carboxamide, secreted by isolated strain $P$. chlororaphis PCL1391 from roots of tomato plants have the potential to solublize iron $[48,43]$. Biocontrol of alfalfa disease can be done by $B$. cereus UW85 strain which produce kanosamine and zwittermicin A [49]. With respect to usage of PGPR as a tool in a biological solution, Paenibacillus spp, and Bacillus are frequently documented these strains can show more population stability when used as inoculums [50].

\section{Conclusion}

Biocontrol mechanisms exhibited by PGPR are of intensive importance for plants growth and metabolism. The mechanisms exerted by PGPR can elicit or induce resistance and have essential functions in microbial antagonisms. These antagonistic and resistant inducing bacteria might be helpful in offering an alternative environmentally friendly biofertilizers formulation of new inoculants for disease management and improving crop systems.

\section{Authors' contributions}

Wrote the paper: R Mazhar \& M Saeed, Arranged the paper: N Ilyas, NI Raja \& M Hussain, Reviewed the paper: W Seerat, H Qureshi \& S Shabir.

\section{References}

1. Somers E, Vanderleyden J \& Srinivasan M (2004). Rhizosphere bacterial signalling: A love parade beneath our feet. Crit Rev Microbiol 30: 205-240.

2. Siddiqui Z (2006). PGPR: Prospective Biocontrol Agents of Plant Pathogens. PGPR: Biocontrol and Biofertilization 111-142.

3. Meyer JB, Lutz MP, Frapolli M, PechyTarr M, Rochat L, Keel C, Défago G \& Maurhofer M (2010). Interplay between wheat cultivars, biocontrol pseudomonads, and soil. Appl Environ Microbiol 76: 6196-204.

4. Kokalis-Burelle N, Kloepper JW \& Reddy MS (2006). Plant growthpromoting rhizobacteria as transplant amendments and their effects on indigenous rhizosphere microorganisms. Appl Soil Ecol 31(12): 91-100.

5. Dobbelaere S, Vanderleyden J \& Okon Y (2003). Plant growth-promoting effects diazotrophs in the rhizosphere. Crit Rev Plant Sci 22: 107-149.

6. Whipps JM 2001. Microbial interactions and biocontrol in the rhizosphere. $J$ Exp Bot 52(Suppl 1): 487-511.

7. Nadeem SM, Zahir ZA, Naveed M \& Arshad M (2007). Preliminary investigations on inducing salt tolerance in maize through inoculation with rhizobacteria containing ACCdeaminase activity. Can J Microbiol 53: 1141-1149.

8. Burdman S, Jurkevitch E \& Okon Y (2000). Recent advance in the use of plant growth promoting rhizobacteria (PGPR) in agriculture. In: Microbial Interaction In Agriculture Forestry, Vol 
II, Subba Rao NS \& Dommergues YR 229-250.

9. Castro-Sowinski S, Herschkovitz Y, Okon Y \& Jurkevitch E (2007). Effects of inoculation with plant growthpromoting rhizobacteria on resident rhizosphere microorganisms. FEMS Microbiol Lett 276: 1-11.

10. Ramette A, Frapolli M, Fischer-Le Saux M, Gruffaz C, Meyer JM, Défago G, Sutra L \& Moënne-Loccoz Y (2011). Pseudomonas protegens sp. nov., widespread plantprotecting bacteria producing the biocontrol compounds 2,4-diacetylphloroglucinol and pyoluteorin. Syst Appl Microbiol 34: 180-8.

11. Bisseling T, Dangl JL \& Schulze-Lefert, $P$ (2009). Next-Generation Communication. Science 324: 691-691.

12. Okon Y \& Labandera-Gonzales CA (1994). Agronomic application of Azospirillum: an evaluation of 20 years worldwide field inoculation. Soil Biol Biochem 26: 1591-1601.

13. Surette MA, Sturz AV, Lada RR \& Nowak J (2003). Bacterial endophytes in processing carrots (Daucus carota L. var. sativus): their localization, population density, biodiversity and their effects on plant growth. Plant and Soil 253: 381-390.

14. Bulgari D, Casati P, Brusetti L, Quaglino F, Brasca M, Daffonchio D \& Bianco PA (2009). Endophytic bacterial diversity in grapevine (Vitis vinifera $\mathrm{L}$.) leaves described by $16 \mathrm{~S}$ rRNA gene sequence analysis and length heterogeneity-PCR. $J$ Microbiol 47: 393-401.

15. Rosenblueth M \& Martínez-Romero E 2006. Bacterial endophytes and their interactions with hosts. Molecular plant-microbe interactions. Phytopathology 1 9: 827-837.
16. Long HH, Schmidt DD \& Baldwin IT (2008). Native Bacterial Endophytes Promote Host Growth in a SpeciesSpecific Manner; Phytohormone Manipulations do not result in common growth responses. PLOS One 3: 2702.

17. Mano H \& Morisaki H (2008). Endophytic Bacteria in the Rice Plant. Microbes and Environments 23: 109117.

18. Chakraborty U, Chakraborty B \& Basnet M (2006). Plant growth promotion and induction of resistance in Camellia sinensis by Bacillus megaterium. $J$. Basic Microbiol 46: 186-195.

19. Nowak J \& Shulaev V (2003). Priming for transplant stress resistance in in vitro propagation. In Vitro Cell Dev Biol Plant 39: 107-124.

20. Ramamoorthy V, Viswanathan R, Raguchander T, Prakasam V \& Smaiyappan R (2001). Induction of systemic resistance by plant growthpromoting rhizobacteria in crop plants against pests and diseases. Crop Prot. 20: $1-11$.

21. Mpiga P, Belanger RR, Paulitz TC \& Benhamou N (1997). Increased resistance to Fusarium oxysporum f. sp. radicis-lycopersici in tomato plants treated with the endophytic bacterium Pseudomonas fluorescens strain 63-28. Physiol Mol Plant Pathol 50: 301-320.

22. Compant S, Reiter B, Sessitsch A, Nowak J, Cle'ment C \& Ait Barka E (2005). Endophytic colonization of Vitis vinifera L. by a plant growthpromoting bacterium, Burkholderia sp. strain PsJN. Appl Environ Microbiol 71: 1685-1693.

23. Duijff BJ, Gianinazzi-Pearson V, Lemanceau P (1997). Involvement of the outer membrane lipopolysaccharides in the endophytic colonization of tomato roots by biocontrol Pseudomonas 
fluorescens strain WCS417r. New Phytologist 135: 325-334.

24. Chen C, Belanger RR, Benhamou N \& Paulitz TC (2000). Defense enzymes induced in cucumber roots by treatment with plant growth-promoting rhizobacteria (PGPR) and Pythium aphanidermatum. Physiol Mol Plant Pathol 56: 13-23.

25. Mathesius U, Mulders, Gao MS, Teplitski M, Caetano-Anolles G, Rolfe BG \& Bauer WD (2003). Extensive and specific responses of a eukaryote to bacterial quorum-sensing signals. Proc Natl Acad Sci USA 100: 1444-1449.

26. Austin MB \& Noel AJP (2003). The chalcone synthase superfamily of type III polyketide synthases. Nat Prod Rep 20: 79-110.

27. Yang J, Kloepper JW \& Ryu CM (2009). Rhizosphere bacteria help plants tolerate abiotic stress. Trends Plant Sci 14: pp.1-4.

28. Dimkpa C, Weinan T \& Asch F (2009). Plant-rhizobacteria interactions alleviate abiotic stress conditions. Plant Cell Environ 32: 1682-1694.

29.Molina-Favero C, Creus CM Simontacchi M, Puntarulo S \& Lamattina L (2008). Aerobic nitric oxide production by Azospirillum brasilense Sp245 and its influence on root architecture in tomato. Mol Plant Microbe Interact 21: 1001-1009.

30. Duffy B, Schouten A \& Raaijmakers JM (2003). Pathogen self-defense: mechanisms to counteract microbial antagonism. Annu Rev Phytopathol 41: 501-538.

31. Sturz AV, Christie BR \& Nowak J (2000). Bacterial endophytes: potential role in developing sustainable systems of crop production. Crit Rev Plant Sci 19: $1-30$.

32. Von Bodman SB, Bauer WD \& Coplin DL (2003). Quorum sensing in plant- pathogenic bacteria. Аnnu Rev Phytopathol 41: 455-482.

33. Dong YH, Zhang XF, Xu JL \& Zhang LH (2004). Insecticidal Bacillus thuringiensis silences Erwinia carotovora virulence by a new form of microbial antagonism, signal interference. Appl Environ Microbiol 70: 954-960.

34. Chernin L \& Chet I (2002). Microbial enzymes in biocontrol of plant pathogens and pests, p. 171-225. In R. G. Burns and R. P. Dick (ed.), Enzymes in the environment: activity, ecology, and applications. Marcel Dekker, New York, N.Y.

35. Castillo UF, Strobel GA, Ford EJ, Hess WM, Porter H, Jensen JB, Albert H, Robison R, Condron MAM, Teplow DB, Steevens D \& Yaver D (2002). Munumbicins, wide-spectrum antiobiotics produced by Streptomyces NRRL 30562, endophytic on Kennedia nigriscans. Microbiology 148: 26752685.

36. Miethke M \& Marahiel M (2007). Siderophore-based iron acquistion and pathogen control. Microbiol Mol Biol Rev 71(Suppl 3): 413-451.

37. Challis GL (2005). A widely distributed bacterial pathway for siderophore biosynthesis independent of non-ribosomal peptide synthetases. Chem biochem 6(4): 601-11.

38. Raymond KN, Dertz EA, Kim SS (2003). Enterobactin: an archetype for microbial iron transport. $P$ Natl Acad Sci USA 100: 3584-3588.

39. Tian F, Ding Y, Zhu H, Yao L \& Du B (2009). Genetic diversity of siderophore-producing bacteria of tobacco rhizosphere. Brazilian $J$ Microbiol 40 (Suppl 2): 276-284.

40. Pedraza R, Motok J, Tortora M, Salazar S \& Díaz-Ricci J (2007). Natural occurrence of Azospirillum brasilense 
in strawberry plants. Plant and Soil 295: 169-178.

41. Lugtenberg B \& Kamilova F (2009). Plant-growth-promoting rhizobacteria. Annu Rev Microbiol 63:541-55.

42. Duffy B (2003). Pathogen self-defense: Mechanisms to counteract microbial antagonism. Annu Rev Phytopathol 41: 501-38.

43. Haas D \& Défago G (2005). Biological control of soil-borne pathogens by fluorescent pseudomonads. Nat Rev Microbiol 3: 307-319.

44. Wang C, Knill E, Glick BR \& Defago G (2000). Effect of transferring 1aminocyclopropane-1- carboxylic acid (ACC) deaminase genes into Pseudomonas fluorescens strain CHAO and its gacA derivative CHA96 on their growth promoting and disease suppressive capacities. Can J Microbiol 46: 898-907.

45. De Souza JT, Arnould C, Deulvot C, Lemanceau P, Gianinazzi- Pearson V \& Raaijmakers JM (2003). Effect of 2,4diacetylphloroglucinol on Pythium: Cellular responses and variation in sensitivity among propagules and species. Phytopath 93: 966-975.
46. Chin-A-Woeng TF, Bloemberg GV \& Lugtenberg BJ (2003). Phenazines and their role in biocontrol by Pseudomonas bacteria. New Phytol 157: 503-523.

47. Maksimov IV, Abizgil'dina RR \& Pusenkova LI (2011). Plant growth promoting rhizobacteria as alternative to chemical crop protectors from pathogens (Review). Appl Biochem Microbiol 47: 333-345.

48. Hernandez ME, Kappler A \& Newman DK (2004). Phenazines and other redox-active antibiotics promote microbial mineral reduction. Appl Environ Microbiol 70: 921-928.

49. Silo-Suh LA, Lethbridge BJ, Raffel SJ, $\mathrm{He} \mathbf{H}$, Clardy $\mathbf{J} \&$ Handelsman $\mathbf{J}$ (1994). Biological activities of two fungistatic antibiotics produced by Bacillus cereus UW85. Appl Environ Microbiol 60: 2023-2030.

50. Kokalis-Burelle N, Kloepper JW \& Reddy MS (2005). Plant growthpromoting rhizobacteria as transplant amendments and their effects on indigenous rhizosphere microorganisms. Appl Soil Ecol 31: 91-100. 